\title{
ELŻBIETA ADAMIAK \\ Edyty Stein i Jana Pawła II teologiczna wizja kobiecości
}

O znaczeniu osoby i twórczości Edyty Stein (1891-1942) dla papieża Jana Pawła II (1920-2005) nie trzeba przekonywać. To on dokonał jej beatyfikacji, 1 maja 1987 r. w Kolonii. To on kanonizował ją 11 października 1998 r. To on w końcu 1 października 1999 r. ogłosił ją motu proprio Spes aedificandi - wraz ze św. Brygidą Szwedzką i św. Katarzyną ze Sieny - Patronką Europy ${ }^{1}$.

Można też wskazywać na wiele podobieństw na płaszczyźnie intelektualnej i duchowej, które skłaniają do podejmowania pytań o ujęcia pewnych kwestii przez Edytę Stein i Jana Pawła II. Spośród podobieństw, które wydają się mieć największe znaczenie dla interesującego nas tematu, należy wskazać formację filozoficzno-teologiczną. Oczywiście oboje realizowali ją w szczegółach na różny sposób, treściowo pozostaje jednak stwierdzić, że oboje wiązali w swojej refleksji oba te poziomy, jak też, że dla obojga szczególne miejsce w obszarze badań zajmowała fenomenologia jako kierunek filozoficzny oraz pisma św. Jana od Krzyża w obszarze badań teologicznych.

Radykalizm opowiedzenia się za Jezusem doprowadził oboje do decyzji o życiu w bezżeństwie. Decyzją Kościoła katolickiego oboje są obecnie czczeni oficjalnie - Edyta Stein pod karmelitańskim imieniem św. Teresy Benedykty od Krzyża, Karol Wojtyła jako bł. Jan Paweł II.

Warto wspomnieć również bliskość miejsca śmierci Edyty Stein - w obozie koncentracyjnym Auschwitz-Birkenau, z miejscem urodzenia i przedpapieskiej działalności Karola Wojtyły/ Jana Pawła II. Stąd jego pojmowanie roli św. Edyty

Elżbieta A D A M I A K, dr hab., adiunkt w Zakładzie Teologii Dogmatycznej, Wydział Teologiczny Uniwersytetu im. Adama Mickiewicza w Poznaniu, e-mail: eadamiak@amu.edu.pl

${ }^{1}$ Por. J a n P aw e 1 I I: List apostolski motu proprio Spes aedificandi. „L'Osservatore Romano". Wydanie polskie. R. 20: 1999 nr 12 (218) s. 12 nr 2. 
Stein/ Teresy Benedykty od Krzyża już w okresie papieskim jako rzeczniczki dialogu żydowsko-chrześcijańskiego, którego sam był głębokim orędownikiem. W motu prioprio Spes aedificandi Jan Paweł II pisał dlatego o śmierci Karmelitanki: Jej gtos zlat się z krzykiem wszystkich ofiar tej przerażającej tragedii, lecz zarazem zjednoczyt się z krzykiem Chrystusa na Krzyżu, który nadat ludzkiemu cierpieniu tajemnicza i trwała owocnośc ${ }^{2}$.

Poza wspomnianymi najważniejszymi podobieństwami, można wskazać też na wyraźne różnice. Najistotniejszą wydaje się pełne przełomów światopoglądowych i religijnych życie Edyty Stein oraz naznaczoną pogłębianiem drogę Karola Wojtyły/ Jana Pawła II, charakteryzującą się przede wszystkim stałością kierunku. Stąd wielu widzi w niej patronkę poszukujących. Któż bowiem lepiej zrozumie ludzi przeżywających ogromne przemiany duchowe niż ta, która od wychowania $\mathrm{w}$ rodzinie żydowskiej, poprzez fazę ateizmu doszła do wyznawania katolicyzmu i to jako żyjąca w klasztorze kontemplacyjnym karmelitanka. Dość oczywistą różnicą jest też przynależność narodowa obojga. Edyta Stein była Żydówką rozumiejącą siebie jako obywatelka pruska. Jan Paweł II - Polakiem.

Podobnie oczywista jest kolejna różnica, która jednak ma znaczenie zwłaszcza dla podejmowanego w niniejszym artykule tematu: płeć. Nie jest bowiem obojętne to, iż Edyta Stein podejmując kwestie rozumienia zawodu i powołania kobiet, mówi tym samym również o sobie. Trzeba to zauważyć także pod względem ograniczeń, z jakimi musiała się zmagać w karierze naukowej ${ }^{3}$. Jan Paweł II podejmuje temat, do którego ma dostęp niejako tylko z zewnątrz.

Istotne jest w końcu wskazanie różnicy epok, w którym powstawały pisma, będące podstawą źródłową tego artykułu. Mimo iż drogi życiowe obojga autorów czasowo nachodzą na siebie, uwzględnione zostaną w podjętej analizie prace Edyty Stein z lat $1928-1933^{4}$ oraz pisma papieskie Jana Pawła II, a zatem z lat

\footnotetext{
${ }^{2}$ Tamże, s. 15 pkt 9.

${ }^{3}$ Myślę głównie o uniemożliwieniu przystąpienia do habilitacji. Pisała o tym do swego ówczesnego przyjaciela, Romana In garden a: Prób habilitowania się mam już serdecznie dosyć. Marnuje się na to tak wiele sit i czasu, których można by użyć w lepszej sprawie (Św. Teresa Benedykta od Krzyża. Edyta S t e i n: Autoportret z listów: Listy do Romana Ingardena. Tłum. J. I. A d a m s k a. Kraków 2004). Życie potwierdziło jej słowa: jej spuścizna naukowa i pisarska wydaje się bardziej promieniować niż naukowe dokonania jej kolegów, którzy na takie bariery formalne nie natrafili, a jednak ich nazwiska mówią coś tylko wąskiemu kręgowi fachowców.

${ }^{4} 1$ stycznia 1922 r. Edyta S te i n przyjęła chrzest w Kościele katolickim, pragnąc od razu wstąpić do zakonu. Za radą kierownika duchowego odłożyła tę decyzję. Pracowała jako nauczycielka w Spirze (niem. Speyer), angażując się jednocześnie między innymi na rzecz kobiet. W 1932 r. podjęła pracę jako docentka w Niemieckim Instytucie Pedagogiki Naukowej w Monastyrze (niem. Münster), którą to posadę - jako Żydówka - musiała złożyć już rok później. Właśnie ten czas - w Spirze i Monastyrze - charakteryzuje duża aktywność wykładowa Stein, która zebrana zostanie potem w książkę podsumowującą jej spojrzenie na rolę kobiet. Teksty te zebrane zostaną w tomie: Die Frau. Fragestellungen und Reflexionen. Freiburg i. B. 2005 (w ramach Edith-Stein-
} 
1978-20055 . Można zatem badać jedynie kwestię możliwego wpływu myślenia E. Stein na Papieża z Polski. Podstawowym pytaniem, na które poszukiwana będzie odpowiedź, jest zatem, czy w nauczaniu Jana Pawła II można odnaleźć ślady inspiracji Steinowską myślą o kobiecości? Jeśli tak, które elementy zostały przejęte i w jaki sposób wbudowane w papieską teologię kobiecości? Podejmując ten temat uwzględniać należy przyjęty zwyczaj, iż w dokumentach papieskich brak bezpośrednich odwołań do autorek i autorów, których myślą się inspirował, zwłaszcza współczesnych lub żyjących w nieodległej epoce. Postawione pytanie dotyczy zatem możliwej recepcji pośredniej myśli Edyty Stein w nauczaniu Jana Pawła II o kobietach.

Zakres tematyczny obejmuje tylko ogólny, antropologiczno-teologiczny poziom rozważań obojga autorów, na boku pozostawiając wynikające stąd konsekwencje eklezjologiczne czy mariologiczne. Zbyt daleko idące byłoby też podejmowanie dyskutowanej kwestii możliwego feministycznego odczytania przesłania Edyty Stein o roli kobiet w Kościele i społeczeństwie. Każde z tych zagadnień warte jest oddzielnego opracowania ${ }^{6}$. W artykule przyjęto metodę analizy tekstu, jak również metodę porównania wyników tejże analizy, co zostanie przedstawione w syntetycznych wnioskach.

\section{I. „Żadna kobieta nie jest tylko kobietą". Edyty Stein teologiczna wizja kobiecości}

W tomie będącym spojrzeniem na wybitnych teologów XX wieku kręgu języka niemieckiego, wydanym staraniem polskiego Towarzystwa Teologów Dogmatyków, znalazła się prezentacja osoby i dzieła Edyty Stein, a jej autor, Paweł Warchoł, nie uzasadniał teologicznego wymiaru jej twórczości, uznając go za

Gesamtausgabe). W języku polskim wydane najpierw: Kobieta - jej zadanie według natury $i$ łaski. Tłum. J. I. A d a m s k a. Tczew 1999; następnie w formie wydania krytycznego: Edyty Stein refleksje o kobiecie. Tłum. J. I. A d a m s k a, M. G r z y w a c z. Borne Sulinowo 2005.

${ }^{5} \mathrm{Z}$ bogatego nauczania $\mathrm{J}$ a n a $\mathrm{P}$ a w $ł$ a I I należy uwzględnić przede wszystkim pierwszy w historii oddzielny dokument papieski, poświęcony tematyce kobiecej, List apostolski Mulieris dignitatem z okazji roku maryjnego o godności i powołaniu kobiety, wydany w $1988 \mathrm{r}$. Poza tym tematyce kobiecej poświęcone były: List apostolski Ordinatio sacerdotalis o udzielaniu święceń kapłańskich wyłącznie mężczyznom z 1994 r. oraz List A ciascuna di voi do kobiet całego świata, wydany z okazji Światowej Konferencji ONZ w Pekinie poświęconej kobiecie z 1995 r. W wielu dokumentach i wystąpieniach Papież nawiązywał do tematyki kobiecej, np. w adhortacji Familiaris consortio (nr 22-24), encyklice Redemptoris Mater ( $\mathrm{nr} 46$ ), adhortacji Christifedels laici, (nr 49 52), encyklice Evangelium vitae ( $\mathrm{nr} 99$ ), adhortacji Ecclesia in Africa ( $\mathrm{nr} 82$ ), adhortacji Vita consecrata ( $\mathrm{nr}$ 57-58), adhortacji Ecclesia in Europa ( $\mathrm{nr}$ 42-43).

${ }^{6} \mathrm{Na}$ ten temat por. zwłaszcza U. G a h 1 i n g s: Geschlechter-Realitäten. Edith Steins Beitrag zur Theorie der geschlechtlichen Differenzierung. „Edith Stein Jahrbuch“. R. 2004 s. 131-156; A. G r z e g o r c z y k: Nauka Edyty Stein o kobiecie wobec wspótczesnych tendencji feministycznych. W: Św. Teresa Benedykta od Krzyża (Edyta Stein) - Kobieta i Karmelitanka Bosa - Patronka Europy. Poznań 2001 s. 37-60. 
oczywisty ${ }^{7}$. Wydaje się, że dzieła Patronki Europy o tematyce kobiecej wymagają więcej wyjaśnienia. Dużo światła na ten wymiar jej dzieła rzuca praca Doroty Dźwig, która podkreśla, że Stein, stawiając pytanie o specyfikę kobiecą, odwołuje się do szerokiej palety dyscyplin naukowych, od psychologii, socjologii, filozofii po teologię ${ }^{8}$. Dodając, iż jednym z najistotniejszych wątków myśli Stein jest kwestia wykształcenia kobiet, uzasadnionym wydaje się jeszcze dodanie wymiaru pedagogicznego. W każdym razie jest to spojrzenie interdyscyplinarne, integralne, przy czym w sposobie stawiania pytań oraz dochodzenia do odpowiedzi na nie najwyraźniejsze jest podejście filozoficzne. W przyjętej przez Stein metodzie fenomenologicznej zasadnicze znaczenie ma, po pierwsze, doświadczenie źródłowe, następnie - intuicyjne uzasadnienie wyniku poznania, oraz po trzecie, spostrzeżenie go w kontekście innych przedmiotów, poprzez odrębność.

Zarazem jednak Edyta Stein porusza wszystkie „klasyczne” teksty biblijne i teologiczne, które w tradycji Kościoła odcisnęły swe piętno na jego odniesieniu do kobiet - jak pierwsze strony Księgi Rodzaju i Pawłowe nie ma mężczyzny $i$ kobiety (Ga 3,28). W jej refleksjach odnajdziemy stwierdzenia dobrze znane, ale też nowe, zaskakująco aktualne. Wynika to - jak się wydaje - z jej własnego usiłowania nawiązywania do najnowszych osiągnięć naukowych $\mathrm{w}$ dziedzinie badań nad różnicą płciową, z jednoczesną ostrą krytyką - jak to nazywała „bezmyślnego dyletanctwa”, z jakim wielu z upodobaniem wypowiadało się publicznie na ten temat. Wydaje się zatem, że mimo uprzywilejowania spojrzenia fenomenologicznego, uzasadnione jest mówienie o wymiarze teologicznym jej dzieła.

Z przyjęcia na poziomie filozoficznym metody fenomenologicznej wynikają zarazem pytania, które stawia Stein, odnosząc je także do płaszczyzny teologicznej: Czym jest kobieta? (Was ist eine Frau?) Czy istnieje istota kobiety, istota kobiecości? (używa pojęcia Wesen der Frau; często pyta też o species Frau). Czyni tak, choć nieobce jest jej rozeznanie różnorodności sytuacji kobiet, które utrudnia poszukiwanie na tak sformułowane pytania odpowiedzi: W samej rzeczy - pisała - powstaje tu równocześnie trudność: czy można $w$ ogóle mówić o położeniu kobiety [die Frau]. (...) z powodu wielkiej różnorodności typów i indywiduów, trudno mówić o jakimś jednym, wspólnym wszystkim położeniu?. Dążąc do syntezy rozważań Stein nad tym zagadnieniem, można powiedzieć, że dochodzi ona do wniosku, iż species człowiek rozwija się jako podwójne

\footnotetext{
${ }^{7}$ P. W a r c h o ł: Św. Teresa Benedykta od Krzyża (Edyta Stein) i jej teologia. W: Wybitni teologowie XX wieku. Krag języka niemieckiego. Red. J. J e zi e rski, K. P a r y c h. Olsztyn 2006 s. 279-294.

${ }^{8}$ D. D źwig: „Żadna kobieta nie jest tylko kobieta”. Edyty Stein studium o kobiecie. Kraków 2003.

${ }^{9}$ Edyty Stein refleksje o kobiecie, s. 151. Por. S. B i n g g e 1 i: Wstęp. W: tamże, s. XII-XV.
} 
species mężczyzny i kobiety. Inaczej mówiąc - istota człowieczeństwa wyraża się w dwojaki sposób.

Prowadzi to Stein do stwierdzeń na trzech poziomach:

Po pierwsze, wyraźnie mówi o równości wszystkich ze względu na człowieczeństwo. Stąd m.in. wywodzi postulat równych praw wyborczych kobiet, biernego i czynnego, jak też wykształcenia kobiet (pogląd ten można by nazwać egalitaryzmem). Argumentując biblijno-teologicznie Stein podkreśla, że występujące w Biblii rozróżnienie płci nie uprzywilejowuje jednej z nich kosztem drugiej. Brak uzasadnienia poddaństwa czy podporządkowania kobiety względem mężczyzny w Objawieniu. Interpretując opis stworzenia z Księgi Rodzaju Stein stwierdza, iż kobieta, jako towarzyszka i pomocnica mężczyzny, stanowi z nim jedno - najściślejszą wspólnotę miłości ${ }^{10}$.

Po drugie, w dziele Stein znajdziemy stwierdzenia o odmienności, różnicy, które można by ocenić jako bliskie pozycji esencjalistycznych. Istotę kobiecości sprowadza do dwóch postaw duchowych: macierzyństwa, czyli podtrzymywania życia i wszystkich jego przejawów, oraz poznania intuicyjnego i wczuwającego się ${ }^{11}$. Warto zwrócić uwagę na epistemologiczną konsekwencję drugiej części tego spojrzenia: kategoria „wczucia” pojmowana jest nie tylko na poziomie metody poznania istoty kobiecości, ale też jako cecha charakterystyczna poznania kobiecego.

Po trzecie Edyta Stein pisze o indywidualności, która powoduje, że w każdym mężczyźnie i każdej kobiecie owo species, charakterystyczne dla danej płci, niekoniecznie musi realizować się w pełni albo nawet może być całkowicie niezgodne z przyjętą zasadą cech charakterystycznych dla danej płci ${ }^{12}$.

Rozróżnienie tych trzech poziomów wydaje się centralne dla trafnego zrozumienia Edyty Stein teologicznej wizji kobiecości. Widać to dobrze na przykładzie charakterystycznego dla niej języka opisu zadań kobiet: używa niemal zamiennie pojęć zawód i powołanie (niem. der Beruf oraz die Berufung) lub też mówiąc ściślej - uznaje zawód kobiety za powołanie. Odróżnia przy tym zawód od pracy wykonywanej wyłącznie dla celów zarobkowych.

Posługując się tymi pojęciami, najpierw mówi o tym, co specyficzne dla istoty kobiety: Mówiac na temat etosu zawodu kobiet, zakładam równocześnie z góry, że dusza kobieca posiada wtaściwe sobie trwate podstawy, które od wnętrza ksztaltuja jej życie zawodowe; w tym zaś mieści się drugie zatożenie, miano-

\footnotetext{
${ }^{10}$ Por. A. G r z e g o r c z y k, art. cyt., s. 41.

${ }^{11}$ Por. tamże, s. 38.

${ }^{12}$ Przykładem takiego ujęcia są wybrane na śródtytuł artykułu słowa E. S t e i n Żadna kobieta nie jest tylko kobieta (T a ż: Kobieta - jej zadanie wedlug natury i łaski, dz. cyt., s. 16).
} 
wicie, że specyfika kobieca zawiera $w$ sobie powołanie do określonych zadań ${ }^{13}$. Potem jednak dodaje: Nie każda kobieta ucieleśnia w petni kobieca istotę. Różne indywidua wykazuja różne właściwości, a nawet pokrewieństwo z istota męska, uzdalniajace do dziatania niespecyficznie kobiecego ${ }^{14}$. Stein zwraca przy tym uwagę, że przykładem takich zawodów/powołań są święci i zakonnicy ${ }^{15}$. W pewnym sensie przekraczają oni granicę płci: święci mężczyźni mają cechy kobiece, święte kobiety - męskie.

To fundamentalne rozróżnienie natury kobiecej od konkretnej kobiety pozwala E. Stein wielokrotnie powtarzać, że nie istnieje żaden zawód, którego nie mogłaby kobieta wykonywać, i że w związku z tym podział zawodów na męskie i kobiece nie da się utrzymać.

Analogicznie rozróżnienie to pozwala odpowiednio rozumieć wypowiedzi Stein o małżeństwie i macierzyństwie czy też o dziewictwie poświęconym Bogu jako przeznaczeniu kobiety. Pojedyncze, wyjęte z kontekstu zdania mogą bowiem sugerować jednostronność jej podejścia. Czytamy np.: Przeznaczeniem kobiety jest być towarzyszka życia mężczyzny $i$ matka ${ }^{16}$. Jednocześnie znajdziemy inne wypowiedzi, w których powołując się na argumentację teologiczną, w szczególności na dziedzictwo grzechu pierworodnego, twierdzi coś - jak się pozornie może wydawać - przeciwnego: stać się żona i matka nie może być jej [kobiety] jedynym przeznaczeniem ${ }^{17}$.

Podobnie należy odczytywać argumentację związaną z dziewictwem jako drogą życiową kobiet. Stein stwierdza najpierw, iż calkowite oddanie się jest zasada życia zakonnego, z zarazem jedynie możliwym adekwatnym spetnieniem kobiecych tęsknot ${ }^{18}$, by kilka zdań dalej powiedzieć: Czy wszystkie kobiety musza zostać zakonnicami dla wypetnienia swego powołania? Oczywiście, że nie! ${ }^{19}$.

Przedstawione tu syntetycznie poglądy św. Edyty Stein/ Teresy Benedykty od Krzyża na temat podstaw antropologicznych mówienia o zawodzie/powołaniu

${ }^{13}$ T a ż: Kobieta - jej zadanie wedlug natury i łaski, dz. cyt., s. 11. Warto zwrócić uwagę, że w takim to znaczeniu konsekwentnie mówi o Zawodzie mężczyzny i kobiety wedtug natury i łaski, a zatem nie podejmuje zadań i powołań kobiet abstrahując od zadań i powołań mężczyzn.

${ }^{14}$ Tamże, s. 85. Por. także - tamże, s. 161-163; 175-177; 180; 190.

${ }^{15}$ Por. Edyty Stein refleksje o kobiecie, dz. cyt., s. 92-93. Szerzej na ten temat zob. M. W a 1 u ś: Świętość kobiet i kategoria płci. Recepcja nauczania Kościoła na temat kobiet a opisy hagiografii. W: Godzina kobiet? Recepcja nauczania Kościoła rzymskokatolickiego o kobietach w Polsce 1978-2005. Red. E. A d a mi ak, M. Chrzą s towska. Poznań 2008 s. 175-187. W aluś wykazuje, że opis ten odnaleźć można także w odniesieniu do samej S te i n. Jej przyjaciółka, J a d w i g a C o n r a d opisuje ją właśnie w takich kategoriach. Zob. J. A d a m s k a: Święta Edyta Stein. Kraków 2003 s. 104.

${ }^{16}$ T a ż: Kobieta - jej zadanie wedlug natury i laski, dz. cyt., s. 11. Por. tamże, s. 84; 98.

17 Tamże, s. 172. Por. tamże, s. 75.

18 Tamże, s. 21. Por. tamże, 188.

${ }^{19}$ Tamże, s. 22. 
kobiet w Kościele i społeczeństwie każą wyeksponować jako najistotniejsze trzy poziomy ujmowania istoty kobiety czy też istoty kobiecości: co do równości, co do odmienności, co do indywidualności.

Zależnie od głoszonej współcześnie antropologii płci podlegają one różnym ocenom. Częściowo wynikać to może z niepełnego odczytania myśli Filozofki i Karmelitanki, tzn. z pominięcia ich wielowymiarowości, a przez to formułowania na poziomie ogólno-obowiązującym nawet tam, gdzie poszczególne wypowiedzi Stein wzajemnie się relatywizują.

Jakkolwiek stwierdzenia o równej godności kobiet i mężczyzn mogą dziś wydawać się oczywiste, dalekie jest ono jeszcze do przekucia na praktykę codzienną. $Z$ drugiej strony stwierdzenia o podejściu indywidualnym do każdej i każdego zdają się współbrzmieć z dzisiejszymi dążeniami do indywidualizmu, trzeba wyraźnie wskazać, że w koncepcji Edyty Stein niezwykle ważną rolę odgrywała też etyka i pojmowanie odpowiedzialności.

\section{II. „Niewiasta jest drugim »ja« we wspólnym czlowieczeństwie"20. Jana Pawła II teologiczna wizja kobiecości}

Zanim podjęta zostanie analiza nauczania papieskiego o kobiecości należy przedstawić jego fundament, czyli podstawowy antropologiczny wątek myślenia Jana Pawła II: równość w godności dwojga - kobiety i mężczyzny. Ze względu na częste występowanie tego wątku w myśli papieskiej niech wystarczy jeden cytat jednoznacznie prezentujący stanowisko Papieża: Godność mężczyzny i kobiety wypływa z faktu, że gdy Bóg stworzyt człowieka, "na obraz Boży go stworzyl, stworzyt mężczyznę i niewiastę" (Rdz 1,27). Zarówno mężczyzna, jak i kobieta zostali stworzeni »na obraz Boży«, to znaczy obdarzeni rozumem $i$ wola, a w konsekwencji także wolnościa. (...) Mężczyzna i kobieta, oboje stworzeni na obraz Boży, sa różni, ale mimo to zasadniczo równi sobie z punktu widzenia swojego człowieczeństwa ${ }^{21}$.

${ }^{20} \mathrm{~J}$ a n P a w e 1 I I: List apostolski Mulieris dignitatem z okazji roku maryjnego o godności i powołaniu kobiety. Watykan 1988 nr 6 (dalej: MD). Por. także: T e n ż e: Katecheza Godność $i$ posłannictwo kobiety chrześcijańskiej, z 22.06.1994 r. W: Nauczanie Kościoła katolickiego. Kraków 2003 [wydanie na płycie CD]. Katechezy cytowane będą przez podanie tytułu i daty wygłoszenia.

${ }^{21} \mathrm{~J}$ a n $\mathrm{P}$ a w e 1 I I: Adhortacja apostolska Ecclesia in Africa, nr 82. Por. także: W perspektywie antropologii chrześcijańskiej każda osoba ludzka ma swoja godność; jako osoba, kobieta nie ma mniejszej godności od mężczyzny (J a n P a w e $\nmid$ I I: Katecheza Godność i postannictwo kobiety chrześcijańskiej, z 22.06.1994 r. Por. T e n ż e: Mężczyzna i niewiasta stworzyt ich, dz. cyt., s. 36). Zob. MD nr 6, 7, 13,16, 29. Szerzej na temat nauczania Kościoła katolickiego o kobietach por. E. A d a mi a k: Nauczanie Kościoła rzymskokatolickiego o kobietach. Ujęcie dogmatyczne. W: Godzina kobiet?, dz. cyt., s. 15-64. 
Nauczanie o równiej godności kobiet i mężczyzn uzasadniane było przez Jana Pawła II nie tylko ze stworzenia - choć egzegeza pierwszych trzech rozdziałów Księgi Genesis zajmowała w nim poczesne miejsce. Papież odwoływał się także do „nowego stworzenia” w Chrystusie: Ewangeliczna »równość«, »równouprawnienie " kobiety i mężczyzny wobec "wielkich spraw Bożych «, która tak przejrzyście uwydatniła się w czynach $i$ stowach Jezusa z Nazaretu, stanowi bardziej oczywista podstawe godności i powolania kobiety w Kościele oraz w świe$\mathrm{cie}^{22}$. Ten zamysł pierwotny godności dwojga, do którego powraca i który umacnia Jezus, jest zarazem kryterium oceny współczesnej rzeczywistości społecznej i kościelnej.

Jan Paweł II wielokrotnie dawał wyraz powszechności i aktualności tego przesłania, które odnosi się ...do wszystkich kobiet $i$ zarazem do każdej z osobna kobiety, bez względu na uwarunkowanie kulturowe, w jakich żyje, niezależnie od takich czy innych jej właściwości duchowych, psychicznych czy cielesnych, jak na przykład wiek, wykształcenie, zdrowie, praca, stan matżeński czy bezżenność ${ }^{23}$.

Kolejny, węższy poziom rozumienia kobiecości przez Jana Pawła II wiąże się z jego pojmowaniem płciowości, które szeroko omawiał w cyklu katechez środowych na początku swego pontyfikatu. Nauczał wówczas: Cielesność $i$ ptciowość nie utożsamiaja się bez reszty. Jakkolwiek bowiem ciało ludzkie w swej normalnej konstytucji zawsze nosi w sobie znamiona ptci, jest z natury męskie lub kobiece - to jednakże fakt, że człowiek »jest ciatem«, wchodzi w strukture osobowego podmiotu $w$ znaczeniu bardziej podstawowym niż fakt, że jest on $w$ swej somatycznej konstytucji, jako człowiek, mężczyzna lub kobieta ${ }^{24}$. Płciowość człowieka była więc dla Papieża kategorią osobową, obejmującą cielesność człowieka, ale nie sprowadzalną do niej. Tego rodzaju podejście do kategorii płci miało wpływ na papieskie rozumienie kobiecości.

Ponownie bowiem odwoływał się Papież do Księgi Rodzaju 1,27: W ten sposób zostaje wyrażona różnica płci, a zwłaszcza ich konieczna komplementarność. Można by powiedzieć, że święty autor pragnie z naciskiem podkreślić, że ostatecznie kobieta $w$ stopniu nie mniejszym niż mężczyzna nosi $w$ sobie podobieństwo do Boga, $i$ że zostala stworzona na obraz Boży w tym, co jest specyficzne dla jej osoby jako kobiety, a nie tylko w tym, co ma wspólnego z mężczyzną.

${ }^{22}$ MD nr 16. Por. MD nr 13.

${ }^{23} \mathrm{MD} \mathrm{nr}$ 29. Mówiąc słowami J a n a $\mathrm{P}$ a w ł a I I, chciał on się zwrócić do wszystkich kobiet i zarazem do każdej z osobna kobiety (MD nr 29). Używał też pojęcia „kobiecości”, rzadziej „natury kobiecej”, a także odczytywał biblijny "paradygmat» niewiasty (MD nr 19, 22, 30), czyli zamysłu Bożego określającego posłannictwo kobiety, paradygmatu rozumianego ontologicznie, ponadczasowo.

${ }^{24} \mathrm{~J}$ a n P a w e 1 I I: Mężczyzna i niewiasta stworzyt ich. Odkupienie ciała a sakramentalność małżeństwa. Watykan 1986 s. 33. Por. tamże, s. 42-43, 59-61, 81-82. 
Jest to równość w różnorodności $i^{25}$. We fragmencie tym dochodzi do głosu dwojaka perspektywa patrzenia na kobiecość przez Jana Pawła II: przez pryzmat równości (czyli egalitarna) oraz przez pryzmat różnorodności, którą sam Papież nazywa tezą komplementarności płci. Tę drugą rozwija na dwa sposoby: Po pierwsze, przez opis, wymienianie cech, które wiąże z kobiecością (metoda deskryptywna). Są to następujące cechy: wrażliwość, dyspozycja do zwrócenia do konkretnego człowieka, troskliwość, zwłaszcza o najbardziej potrzebujących, a więc cechy związane $\mathrm{z}$ dbaniem o relacje międzyludzkie ${ }^{26}$. Ponieważ Jan Paweł II opisuje jako analogiczny do kobiecości fenomen męskości, konsekwentnie: mężczyźni sa bardziej nastawieni na aktywność zewnętrzna, potrzebuja więc pomocy kobiet, by nie zaniedbywać relacji międzyosobowych oraz by pogłębiać jedność serc ${ }^{27}$. W taki sposób dokonywać ma się według Papieża dopełnianie płci.

Po drugie, tezę o komplementarności rozwijał Papież poprzez nauczanie o charakterze wyraźniej normatywnym (metoda preskryptywna). W tego rodzaju wypowiedziach podstawowym wyróżnikiem kobiecości jest jej ,inność” od męskości. Najbardziej syntetycznie fundament tej kategorii wypowiedzi oddają słowa Jana Pawła II: Niewiasta jest drugim »ja« we wspólnym człowieczeństwie ${ }^{28}$. Trudno na tym poziomie mówić o wzajemnym tłumaczeniu i dopełnianiu się męskości i kobiecości, jako kobiece zostaje określone bowiem to, co różni kobietę od mężczyzny ${ }^{29}$. Jedną z konsekwencji takiego ujęcia jest traktowanie macie-

25 Jan Pawe 1 I I: Katecheza Godność $i$ postannictwo kobiety chrześcijańskiej, z 22.06.1994 r. W: Nauczanie Kościoła katolickiego. Kraków 2003 [wydanie na płycie CD]. Por. J. M e 1 o n o w s k a: John Paul's Concept of Femininity and the Critique of Human Essentialism. W: Gender and Religion in Central and Eastern Europe. Red. E. A d a m i a k, M. C h r z ą s t o w s k a, C. M e th u e n, S. S o b k o w i a k. Poznań 2009 s. 127-136.

${ }^{26}$ Por. MD nr 16, 18, 19, 21, 30. Kwestię ujęcia kobiecości przez J a n a P a w ł a I I podejmowałam wielokrotnie w moich publikacjach, począwszy od E. A d a mi a k: Milczaca obecność. O roli kobiety w Kościele. Warszawa 1999; po E. A d a m i a k: Nauczanie Kościoła rzymskokatolickiego o kobietach, art. cyt.

${ }^{27} \mathrm{~J}$ a n P a w e 1 I I: Katecheza Obecność Maryi u początku Kościoła, z 6.09.1995 r. W: Nauczanie Kościoła katolickiego. Kraków 2003 [wydanie na płycie CD]. Por. także inną wypowiedź w podobnym duchu: kobiecość niejako odnajduje siebie w obliczu męskości, podczas gdy męskość potwierdza się przez kobiecość (J a n P a w e ł I I: Mężczyzną i niewiastą stworzył ich, dz. cyt., s. 42). Por. także: MD nr 10, 25.

${ }^{28}$ MD nr 6. Myśl ta pojawia się także w: T e n ż e: Mężczyzna i niewiasta stworzyt ich, dz. cyt., s. 16, 37; T e n ż e: Katecheza Godność i posłannictwo kobiety chrześcijańskiej, z 22.06.1994 r. W: Nauczanie Kościoła katolickiego. Kraków 2003 [wydanie na płycie CD]. Zwłaszcza w katechezach poświęconych „teologii ciała” rozwinięta jest myśl, utożsamiająca pierwszego człowieka z mężczyzną. Konsekwencją tego jest potwierdzanie, iż kobieta to „druga płeć”. W takim kontekście trudno za przypadkową uznać kolejność wymieniania płci: w Liście o godności i powołaniu kobiety Mulieris dignitatem w ogromnej większości przypadków na pierwszym miejscu wymieniany jest mężczyzna, a na drugim kobieta.

${ }^{29}$ Por. MD nr 10, 11, 14, 20, 25, 31; J a n P a w eł I I: Mężczyzna i niewiasta stworzyt ich, dz. cyt., s. 85 . 
rzyństwa jako podstawowego powołania kobiety. Także dziewictwo, o którym pisał Papież w liście apostolskim Mulieris dignitatem, pojmowane jest przede wszystkim jako macierzyństwo duchowe. Normatywność nauczania papieskiego o macierzyństwie wyraża się także $\mathrm{w}$ oceniających sformułowaniach na temat innych wyborów, dokonywanych przez kobiety: Wytaniajaca się z Ewangelii koncepcja osobowości i ludzkiej komunii nie pozwala aprobować dobrowolnego wyrzeczenia się macierzyństwa jedynie ze względu na chęć osiagnięcia dobrobytu materialnego bądź satysfakcji z petnienia określonej dziatalności. Jest to bowiem wypaczenie osobowości kobiety, która znajduje naturalny rozkwit w macierzyństwie ${ }^{30}$.

Wyraźny akcent na macierzyństwo w nauczaniu papieskim widoczny jest również poprzez porównanie z pojawiającą się zdecydowanie rzadziej ideą kobiety jako siostry mężczyzny. Nie chodzi tu jedynie o biologicznie rozumiane relacje siostrzańskie. W Liście Mulieris dignitatem mówił Papież o kobiecie, iż zadana jest mężczyźnie jako siostra $w$ tym samym człowieczeństwie ${ }^{31}$, a na zakończenie błogosławił im jako siostrom $w$ Chrystusie ${ }^{32}$. Rzadkość pojawiania się kategorii siostry w o pisie relacji między kobietami i mężczyznami jest o tyle znacząca, że wyraźniej sugeruje ona równość między przedstawicielami obojga płci.

Przykład papieskiego pojmowania macierzyństwa i siostrzaności ujawnia pewną trudność w recepcji jego nauczania. Pewne szczegółowe aspekty nauczania o komplementarności płci zdają się sugerować nie tylko różnicę, ale niemal nierówność pomiędzy płciami, choć inne wypowiedzi - nazywane w artykule egalitarnymi - wyraźnie mówią o równości w godności.

Innym przykładem tego rodzaju trudności jest nauczanie Jana Pawła II o relacjach oblubieńczych pomiędzy Chrystusem a Kościołem. Z jednej strony podkreślał Papież, że poprzez Kościól, wszyscy ludzie - zarówno kobiety, jak i mężczyźni - sa powołani, by być »Oblubienica " Chrystusa, Odkupiciela świata. W taki sposób »bycie oblubienicą", a więc to, co »kobiece», staje się symbolem powszechności tego, co »ludzkie«, stosownie do owych słów Pawłowych: »nie ma już mężczyzny ani kobiety, wszyscy bowiem jesteście kimś jednym w Chrystusie Jezusie« $(G a$ 3,28). (...) Chrystus jest Oblubieńcem. Wyraża się w tym prawda o

${ }^{30} \mathrm{~J}$ a n P a w e 1 I I: Katecheza Niezwykła wielkość macierzyństwa, z 20.07.1994 r. W: Nauczanie Kościoła katolickiego. Kraków 2003 [wydanie na płycie CD]. Szersze omówienie zob. E. A d a m i a k: Nauczanie Kościoła rzymskokatolickiego o kobietach, dz. cyt., s. 33-37.

${ }^{31} \mathrm{MD}$ nr 14.

${ }^{32}$ MD nr 31. Najszerzej idea ta rozwinięta została w Liście do kapłanów na Wielki Czwartek 1995 r., zatytułowanym Znaczenie kobiety w życiu kapłana (nr 4-5), choć i tam pojawia się dopiero po omówieniu relacji kapłana do matki, a cały List kończy się wezwaniem Maryi jako Matki Kościoła i Matki kapłanów (tekst opublikowany 25.03.1995 r. W: Nauczanie Kościoła katolickiego. Kraków 2003 [wydanie na płycie CD]. 
miłości Boga, który "pierwszy« umiłowat (por. $1 \mathrm{~J}$ 4,19), a darem zrodzonym z tej oblubieńczej miłości do człowieka przekroczyt wszystkie ludzkie oczekiwania: "umiłowat do końca" (por. J 13,1). Oblubieniec - Syn wspótistotny Ojcu jako Bóg - stat się Synem Maryi, »Synem Człowieczym", prawdziwym człowiekiem, mężczyzna. Symbol Oblubieńca jest rodzaju męskiego. W tym symbolu męskim jest przedstawiony ludzki charakter miłości, w której Bóg wyraził swa Boska mitość do Izraela, do Kościoła, do wszystkich ludzi ${ }^{33}$. Ponieważ Ecclesia pojmowana jest jako Oblubienica, wszyscy jej członkowie, a więc i kobiety, i mężczyźni, również ci, którzy przyjęli sakrament święceń, mają identyfikować się z symbolem kobiecym. Takie ujęcie - jak się wydaje - stwarza duże możliwości przemyślenia na nowo ról związanych z zadaniami i funkcjami kobiet i mężczyzn w Kościele. Z drugiej strony Jan Paweł II nauczał jednak, że męska strona symboliki - mimo przywołania formuły z Listu do Galatów - nie jest już powszechna, lecz zawężona do jednej płci, co widać zwłaszcza w tych fragmentach dokumentów, w których Jan Paweł II odnosił się do kwestii święceń kapłańskich kobiet ${ }^{34}$.

\section{Podsumowanie}

Podstawowy wątek nauczania Jana Pawła II o godności kobiety, choć wyrażony językiem medytacji biblijnej i przepowiadania, a więc nieco innym językiem niż spisane wykłady Edyty Stein, wydaje się bardzo zbieżny w wymowie do poziomu wypowiedzi, który w odniesieniu do ujęcia Świętej w niniejszym artykule nazwano egalitarnym. W tej fundamentalnej kwestii oboje autorzy są zgodni, choć wydaje się trudne czy wręcz niemożliwe do wykazania, iż myśl ta pojawiła się u Jana Pawła II ze względu na inspirację pismami Edyty Stein. Przekonanie o równej godności kobiet i mężczyzn wydaje się przynależeć bowiem obecnie do powszechnie przyjmowanych, przynajmniej na poziomie deklaratywnym.

Z drugiej strony, wyraźniej normatywna i mająca praktyczne konsekwencje warstwa nauczania Jana Pawła II charakteryzuje jego rozumienie kobiecości jako komplementarnej do wcześniej (milcząco) założonej męskości. Prowadzi do wyraźnego postawienia akcentu na różnicę płciową, tzn. różnicę między mężczyzną a kobietą. Mamy tu analogię do poziomu drugiego w teologicznej wizji kobiecości Edyty Stein. Również u Patronki Europy dochodziło do głosu przekonanie, że macierzyństwo w szerokim sensie, jako dawanie życia, jest podstawowym powo-

${ }^{33} \mathrm{MD}$ nr 25.

${ }^{34}$ Por. MD nr 26. J a n P a w e 1 I I: List apostolski Ordinatio sacerdotalis o udzielaniu święceń kapłańskich wyłącznie mężczyznom. Watykan 1994. Szerzej na ten temat zob. E. A d a m i a k: Nauczanie Kościoła rzymskokatolickiego o kobietach, dz. cyt., s. 57-60; J. M a j e w s k i: Spór o rozumienie Kościoła. Eklezjologiczne uwarunkowania i perspektywy wielkich debat teologicznych na przetomie XX i XXI wieku. Warszawa [b.r.w.] s. 121-140. 
łaniem kobiety. Dodajmy, Jan Paweł II równie szeroko pojmował macierzyństwo. Edyta Stein dostrzegała jeszcze drugą równie ważną postawę kobiecą, powołanie do poznania intuicyjnego i wczuwającego się.

Bardziej zasadnicza różnica między badanymi myślicielami polega jednak na tym, że Stein wyróżniała jeszcze trzeci poziom pojmowania kobiecości, czyli podejście indywidualne. Dlatego to wypracowana na poziomie fenomenologicznym koncepcja odmienności kobiecej weryfikowała się według niej w konkretnych osobach ludzkich - kobietach, które mogą posiadać cechy męskie, oraz mężczyznach, którzy mogą posiadać cechy kobiece. Trudno więc wyczytać w jej pismach wizję kobiecości, która byłaby normatywna. Jeżeli poszukiwać wzoru, który Stein stawiała - byłoby to właśnie odejście od wyłącznie kobiecego pojmowania. Uznawała wszak, że święci - a więc godni naśladowania - zespalali w sobie cechy kobiece i męskie.

Nauczanie papieskie Jana Pawła II nosi oczywiście inny charakter ze względu na sprawowany przez niego urząd Biskupa Rzymu. Wydaje się, że brak odpowiednika trzeciego Steinowskiego poziomu, czyli indywidualnego podejścia, skutkuje uwzględnieniem w niewielkim tylko stopniu różnorodności powołań kobiecych, wielości ich doświadczeń, koncepcji i dróg życia ${ }^{35}$. Wszystko to powoduje, że Jana Pawła II teologiczna wizja kobiecości trudna jest w jednoznacznej ocenie. Z pewnością jest świadectwem wyraźnej ewolucji w nauczaniu Kościoła rzymskokatolickiego o godności i powołaniu kobiety - od modelu podporządkowania płci do modelu komplementarności, głosząc jednocześnie równość kobiet i mężczyzn w godności osobowej. Mimo to normatywna, a nie tylko opisowa koncepcja kobiecości, przy jednoczesnym braku takiego normatywnego modelu dla mężczyzn powodowało ciągłe dyskusje na temat tego wymiaru nauczania papieskiego.

${ }^{35} \mathrm{~W}$ MD jako dwa podstawowe powołania kobiet przedstawione zostały macierzyństwo i dziewictwo; w Liście A ciascuna di voi do kobiet całego świata z 1995 r. zawarta jest lista podziękowań kobietom realizującym różne powołania. Mimo wszystko nie zmienia to podstawowej perspektywy. 